\title{
Interactive comment on "Surface-circulation
} change in the Southern Ocean across the Middle Eocene Climatic Optimum: inferences from dinoflagellate cysts and biomarker paleothermometry" by Margot J. Cramwinckel et al.

G. Raquel Guerstein (Referee)

rogeleguerstein@gmail.com

Received and published: 28 May 2019

The Middle Eocene Climatic Optimum (MECO) is a global warming event at about $40 \mathrm{Ma}$ that interrupted the long-term Cenozoic cooling trend. Up to now only a few studies have focused with enough resolution to evaluate the paleoenvironmental and paleobiotic consequences of this hyperthermal event. In this work Cramwinckel and coauthors have investigated the paleoecological and paleoceanographic repercussions of 
the MECO in the Southweast Pacific Ocean (SWPO) primarily based on organic walled dinoflagellate cysts (dinocysts) and TEX86 palaeothermometry. The most important site analysed in this study is the ODP Site 1170 located on the western side of the South Tasman Rise (STR). The area where this site was drilled is characterised by a notably high sedimentation rate, especially the stratigraphical interval here interpreted as part of the middle Eocene including the MECO.

Despite the absence of key biostratigraphic markers to validate a robust age-depth frame, the results from this study, togeteher with the information from the Site 1172 (Bijl et., 2010, 2011 and 2013a), conform a dataset of very good quality and high potential to respond the questions posed by the authors. However, I have identified several unsubstantiated interpretations and important methodological shortcomings that reduce the relevance of the paper. In the following I list some points that may be of assistance to make the contribution stronger. I am positive that the authors can carry out the proposed modifications, and I recommend publication of the manuscript after major revisions.

My primary concern is related to the lack of physical arguments to explain the proposed change in the Southern Ocean's surface circulation through the MECO. According to the authors (page 13, lines 8 to 11): Throughout the studied middle Eocene interval, dinocyst assemblages at Site 1170 are dominated by Antarctic-endemic taxa. This implies that the Tasman Gateway was influenced by westward atmospheric and surfaceoceanic circulation (i.e., the polar easterlies) around $40 \mathrm{Ma}$, with the $60^{\circ} \mathrm{S}$ front thus located to the north of the gateway and the proto-ACC flowing through the Tasman Gateway (Figure 1b).

Then (page 13, line 19), the authors suggest that during the MECO the East-Australian Current (EAC) waters would reach paleolatitudes somewhat less than $60^{\circ} \mathrm{S}$, represented by the dinocyst assemblages at Site 1172 on the East Tasman Plateau (ETP) (Fig 1C). Such changes in the path of a Western Boundary Current (WBC) have to be driven by a substantial modification of the global wind pattern. a. Add a squematic

Interactive

comment

CPD
Printer-friendly version

Discussion paper 
wind distribution in Fig. 1 A, B and C indicating the latitude of zero wind stress curl.

b. Explain the physical mechanisms conducting to the intensification and southward displacement of the the EAC shown in Fig. 1C.

c. If the changes in the EAC are wind driven, then explain the physical mechanisms by which the MECO was able to change the present distribution of wind stress.

Interactive

comment

d. According of Fig. 1C (representing the MECO situation) the latitude of zero wind stress curl should be about $10-15^{\circ}$ to the south of its present location. In that case the southern portion of the Australo-Antarctic Gulf (AAG) would have been under the influence of the westerlies instead of the polar easterlies. Explain how a proto-Antarctic Counter Current (proto-ACC) would flow through a shallow, partially open Tasman Gateway (TG) as proposed by Bijl et al (2013a and b) under such conditions. I suggest to consider another hypothesis to explain the observed dynocysts distribution. Bearing in mind a TG area located at $\sim 60^{\circ} \mathrm{S}$ during the middle Eocene, the cosmopolitan taxa could actually have been transported eastward through the northern portion of an incipient TG from a PLC source, very much like similar interpetations for an early incipient opening of the Drake Passage (see Scher and Martin, 2006; Livermore et al., 2007, Lagabrielle et al., 2009, González Estebenet et al., 2014). This weak flow would reach the ETP (Site 1172) but not the STR (Site 1170), dominated by the TC and a proto-ACC (Fig 1B with slight modifications). Then it would be easy to explain why the surface temperature rise during the MECO would have resulted in increased production of the cosmopolitan Enneadocysta multicornuta on the ETP but not on the STR, where the dominant species is Enneadocysta dictyostila. This species is the member of the Antarctic endemic assemblage most tolerant to warm surface waters (Fig 4C). The data matrix included in the SI reinforces this hypothesis: E. multicornuta is present in Latrobe-1 borehole but has not been recorded in Hampden Section. This interpretation doesn't need Figure 1C but implies changes in the title and a reorganization of some of the sections accordingly.

Printer-friendly version

Discussion paper 
There are also some methodological weaknesses that are important to take into consideration:

Data and Statistical analyses

a. According to the supplementary information it seems that the statistical analyses are based on proportions (not on counts) and this should be indicated. If they are actually based on proportions the total number of dinocyts counted in each sample should be included in the data tables.

b. Figure 3 illustrates the relative abundances of selected dinocyst biogeographic groups using 4 categories. In the Figure $3 \mathrm{~B}$ (site 1172) the sum of the 4 categories is not $100 \%$ but is not far from it. However, in Fig. 3A (site 1170) it appears that some important information is not taken into account. Indicate which species or groups have not been considered in these cumulative plots and why.

c. In view of the high number of species included in the data tables and that many of them are underepresented is reasonable that only some of the species were plotted in Figures $4 \mathrm{~A}$ and $4 \mathrm{~B}$. Indicate which criteria were followed for the selection of species.

d. Only 4 samples from the Latrobe- 1 borehole were studied and the number of of cyts counted in each sample is very small (based on a minimimum of 50 cyst in each sample). The data available from this site is not of good quality for statistical analyses nor are some of the Hampden Beach samples (based on a minimimum of 90 cyst in each sample). I hardly recommned not to include these samples in the unconstrained NMDS analysis, unless additional counts can make these dinocyst assemblages part of a reliable dataset.

e. Figure 5. Explain the meaning of Enneadocysta - Oligosphaeridium. What is Enneadocysta spp besides Enne-Oli, E.dic and E.mul? Indicate the criteria followed for the selections of species or groups to be plotted in this figure.

Printer-friendly version

Illustration of key markers, taxonomy and dinocyst paleogegraphic affinity

Discussion paper 
a. The middle Eocene dinocysts assemblages are mainly composed of cysts of extint dinoflagellates. Thus, the illustration of key biostratigraphic and palaeoenvironmental markers is a matter of major relevance and should be part of the main paper or included as Supplementary Information.

b. The taxonomy of the Subfamily Wetzelielloideae is an issue of discussion, which is still open (Williams et al., 2015; lakovleva, 2016; Bijl et al., 2016; Williams et al., 2017). In this context the ilustration of the key biomarkers is essential. As things are stand now different research groups can use the same name for different morphotypes and the same morphotype can be named in different ways. One of the key biostratigraphic markers for the MECO, here called Dracodinium rhomboideum, has previously found only at Site 1172 and has not been illustrated by Bijl et al. (2013a). Every research group can call this taxa with different names, but a good illustration allows the dinocyt specialist to know if they are talking about the same thing or not. Unquestionably, the authors have the right to follow the taxonomy they consider better and more useful. However, if they reference a "Comment on a paper", they cannot ignore that there is a "Response to that comment" and it should be mentioned (Williams et al., 2017). The authors are free to follow Fensome et al., 2004 for the wetzelielloid taxonomy, of course, but they have to do it for all the members of the subfamily. For example, Rhombodinium rhomboideum had already been transfered to Dradodinium rhomboideum 15 years ago. A taxonomic appendix should be included to avoid these mistakes.

c. Which is the difference between "endemic SO" and the "so called TF"? I suggest to consider all these taxa as "Antarctic endemics" in order to leave the old name "Transantactic Flora" behind. d. Dinolist (Excell file of SI): Indicate the meaning of "biogeo alt" and " $g$ " and "p" Add a column indicating the source of the biogeo (Bijl et al., 2011, Bijl et al., 2013b, Frieling, Appy Sluijs, 2018... or others).

Terrestrial palynomorphs from the Latrobe-1 borehole

This section is the weakest part of the manuscript. The authors overinterpreted a poor

Printer-friendly version

Discussion paper 
set of data coming from the Latrobe- 1 borehole based on only 4 samples within the interval representing the MECO. The section 4.2.2 Terrestrial Palynology (pages 11-12) is merely descriptive using an open taxonomy with broad links to the modern types and no references to their present-day distribution. The section is closed with the following report: "Within the sporomorph assemblages, there is a slight dominance shift between the major pollen groups towards the top of the interval: the percentages of saccate pollen increase from $\sim 15-20 \%$ to $\sim 40 \%$ upsection, while angiosperms decrease from $\sim 40-60 \%$ to $\sim 25 \% " .$. . Actualy, it is not consistent to describe a palaeoenvironmental trend based on four samples. Moreover, an avaluation of the vegetational modifications as a consequence of the climatic change during the MECO with no records of the pre and post MECO intervals does not have any sense. Furthermore, the authors concluded (page 17, lines 23-25): "Terrestrial palynomorph assemblages suggest a warm temperate rainforest with some paratropical elements that grew along the southeast Australian margin during the MECO", which can be possible, but the statement clearly does not arise from this unsupported analysis.

I suggest to remove this section unless it can be substantially improved.

\section{Other comments}

When different sources are used to reference a concept the references have to follow a chronological order, from the oldest to the youngest. (not in alfabetical order). Example: Page 2, line 22: (Kennett et al., 1974; Cande and Stock, 2004) instead of (Cande and Stock, 2004; Kennett et al., 1974). Check this aspect thoughout the manuscript since there are many of these mistakes.

Page 2, line 28: (Scher and Martin, 2004; Lagabrielle et al., 2009; González Estebenet et al., 2014) instead of (Lagabrielle et al., 2009; Scher and Martin, 2004)

Page 3. Lines 8 and 9: organic walled dinoflagellate cyst assemblage instad of organic dinoflagellate cyst assemblage 
Page 3 line 9: (Wrenn and Beckman, 1982; Wrenn and Hart, 1988; Mao and Mor, 1995; Guerstein et al., 2008; Bijl et al., 2011, 2013a) instead of (Wrenn and Beckman, 1982; Wrenn and Hart, 1988; Bijl et al., 2011, 2013a)

Page 3, line 18: dinocyst assemblages instead of dinocyts assemblages

Page 5, line11: delete a repeted "was not"

Page 5, line: The overlying Wilson Bluff transgressive deposits have an age.... instead of "The overlying Wilson Bluff transgression has an age"

Page 5, line 28: Narrawaturk Formation instead of Narrawaturk formation

Page 6, line 7: Narrawaturk Formation (or Fm) instead of Narrawaturk formation

Page 6, line 13: The Hampden section at Hampden Beach, New Zealand (Figure 2a).... which could have recorded influences of both TC and/or EAC. Explain.

Page 7. Line 6: wetzelielloids or Subfamily Wetzelielloideae insted of "Wetzellioid family"

Page 7. Lines 16-18: "We label taxa without a clear temperature affinity as cosmopolitan, such as those taxa with a distribution that is primarily controlled by other parameters like salinity (e.g., Senegalinium cpx.) or nutrient availability (e.g., protoperidinioids) Add references

Page 7, line 31: where the only species of Deflandrea recorded was D. antarctica insted of: where only the Deflandrea species D. antarctica is present

Page 9 lines 31 -32: Middle Eocene palynomorphs at Site 1170 are generally well preserved and assemblages are dominated (>95\%) by marine forms, mainly dinocysts. Terrestrial palynomorphs occur consistently, but in low relative abundances $(<2 \%$ of palynomorphs). 95 or $97 \%$ ? vs. 2 or $5 \%$ ?

Page 10, lines 2: "possibly from the north". Why?

Printer-friendly version

Discussion paper 
Page 10, lines 6-8: "High abundances of Enneadocysta spp. and peridinioid dinocysts in combination with low diversity indicate a somewhat restricted, eutrophic assemblage with possible low-salinity influences." Add references

\section{Page 11, line 3: MECO cooling ?}

Page 17, lines 2 and 3: Annenberg Formation.... Helmstedt Formation .... Annemberg Formation instead Annenberg formation.... Helmstedt formation .... Annemberg formation

\section{Illustrations}

Be consistent using upper or lower case for the figures. Figure 1 shows $A, B$ and $C$ and the figure caption explains the Figure $1 \mathrm{a}, \mathrm{b}$ and $\mathrm{c}$. See also Figs 2, 3, 4, 6 and supplementary figures.

References mentioned in this comments and not included in the reference list of the manuscript González Estebenet, M. S., Guerstein, G. R., and Alperin, M. I., 2014. Dinoflagellate cyst distribution during the Middle Eocene in the Drake Passage area: paleoceanographic implications. Ameghiniana, 51(6):500-510. DOI: 10.5710/AMGH.06.08.2014.2727.

Guerstein, G.R., Guler, M.V., Williams, G.L., Fensome, R.A., Chiesa, J.O., 2008. Mid Palaeogene dinoflagellate cysts from Tierra del Fuego, Argentina: biostratigraphy and palaeoenvironments. Journal of Micropalaeontology 27: 75-94.

lakovleva, A. I., 2016. Did the PETM trigger the first important radiation of wetzelielloideans? Evidence from France and northern Kazakhstan, Palynology, DOI: 10.1080/01916122.2016.1173121 Livermore, R., Hillenbrand, C. D., Meredith, M. and Eagles, G. (2007). Drake Passage and Cenozoic climate: An open and shut case?. Geochemistry, Geophysics, Geosystems, 8 (1) Q01005.

Mao, S., Mohr, B.A.R., 1995. Middle Eocene dinocysts from Bruce Bank (Scotia Sea, Antarctica) and their paleoenvironmental and paleogeographic implications. Review of

\section{CPD}

\section{comment}

Printer-friendly version

Discussion paper 
Palaeobotany and Palynoly 86: 235-263.

Williams G.L, et al., 2015. Wetzeliella and its allies - the 'hole' story: a taxonomic CPD revision of the Paleogene dinoflagellate subfamily Wetzelielloideae. Palynology 3:141.

Williams, G.L., et al., 2017. A response to 'Comment to Wetzeliella and its allies-the 'hole'story: a taxonomic revision of the Paleogene dinoflagellate subfamily Wetzelielloideae by Williams et al.(2015)'. Palynology 41 (3): 430-437. DOI: 10.1080/01916122.2017.1283367

Interactive comment on Clim. Past Discuss., https://doi.org/10.5194/cp-2019-35, 2019. 